\title{
Effects of model type on mirror neurons activity during a motor skill observation
}

\author{
Ramin Ashraf ${ }^{1 *}$ (iD), Behrouz Abdoli ${ }^{2}$, Reza Khosrowabadi ${ }^{3}$, Alireza Farsi ${ }^{2}$ \\ 1. PhD Student in Motor Learning, Faculty of Sport Science and Health, Shahid Beheshti University, Tehran, Iran \\ 2. Associate Professor, Faculty of Sport Science and Health, Shahid Beheshti University, Tehran, Iran \\ 3. Assistant Professor, Institute for Cognitive and Brain Sciences, Shahid Beheshti University, Tehran, Iran
}

Recieved: 4 Aug. 2019

Revised: 21 Aug. 2019

Accepted: 21 Aug. 2019

Keywords

Modeling

Mu rhythm suppression

Mirror neuron

Motor skill

Corresponding author

Ramin Ashraf, Faculty of Sport

Science and Health, Shahid Be-

heshti University, Tehran, Iran

Email: R_ashraf@sbu.ac.ir

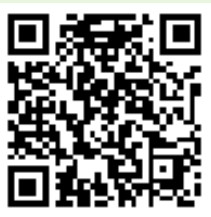

\section{Abstract}

Introduction: The aim of the present study was to investigate the effect of self-modeling, skilled model and novice model on the activity of mirror neurons.

Methods: The current research was a semi-experimental study with an intergroup design. Twenty-one male students (mean age: 19.16 years) in three experimental conditions: 1. self-modeling, 2. skilled model observation, and 3. novice model observation attended in the study. The task of interest was a golf putting task. After providing pre-training considerations, instructions, and initial training in putting skill with emphasis on important stages and tips, the volunteers performed 10 golf putts and their performance was used for providing video tapes for display during recording of brain electrical waves. The second stage was to record the brain electrical waves by observing three types of models. In this recording, 10 10-second videos of golf putting were watched. The operation was repeated three times in the form of counterbalance: within-participant order; 1. by viewing their performance filmed in the previous stage, 2 . by viewing skilled model performances (skilled golfer) and 3. by viewing novice model performances (beginning golfers in putting task). To measure the mu rhythm suppression, ratios of the mu rhythm power during the observed conditions relative to the power over the baseline condition at $\mathrm{C} 3, \mathrm{C} 4$ and CZ scalp locations were used.

Results: Two-way within-subject analysis of variance (ANOVA) showed that the mu rhythm suppression was significantly different among experimental conditions. The results of paired comparisons also indicated that in, self-modeling, suppression of mu rhythm was significantly higher than the other two conditions.

Conclusion: Some of the findings indicate that due to the discrepancy between the ability to perform movement with the observed model execution, the activity of the mirror neurons was lower in the skilled and novice models. The cause of greater mirror neurons activity in self-modeling conditions was also discussed in terms of the Bandura's cognitive-social theory and model-observer similarity. 


\title{
تأثير نوع الكو بر فعاليت نورونهاى آينهاى حين مشاهده يك مهارت حركتى
}

\author{
رامين اشرف"'(D) ، بهروز عبدلى'؛ رضا خسرو آبادى"، عليرضا فارسى'

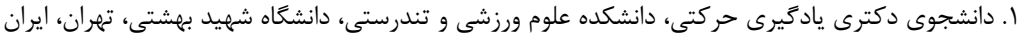

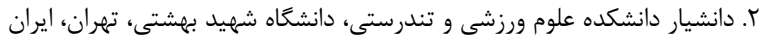

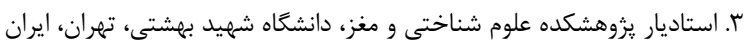

\section{$\Delta \Delta$}

مقلدمه: مطالعه حاضر با هدف بررسى تأثير مشاهده الخوى ماهر، الخوى مبتدى و خودالكودهى بر فعاليت نورونهاى أينهاى انجام كرفت. روش كار: اين يزوهش از نوع نيمهتجربى با طح درون كروهى بود، كه با شركت آ نفر دانشجوى يسر با ميانگين سنى 19/19 سال در سه موقعيت آزمايشى 1. مشاهده خودالكودهى، r. مشاهده الكَوى ماهر و r. مشاهده الكَى مبتدى اجرا شد. تكليف مورد نظر، مهارت پات گَلف بود. بعد از ارائه دستورالعمل و آموزش اوليه مهارت با تأكيد بر مراحل و نكات مهمم

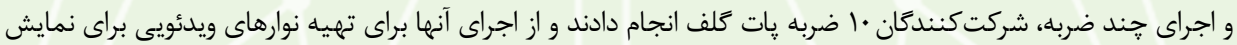
در حين ثبت امواج الكتريكى مغز، فيلمبردارى شد. مرحله دوم، ثبت امواج الكتريكى مغز حين مشاهده سه نوع الكو بود. در اين ثبت، •ا فيلم •ا ثانيهاى از ضربه پات حَلف مشاهده شد. اين عمليات سه بار به شكل موازنه متقابل تكرار شد؛ ا. با مشاهده اجراهاى خود كه در مرحله قبلى فيلمبردارى شده بود، r. مشاهده اجراهاى الكَوى ماهر (كَلفباز ماهر)

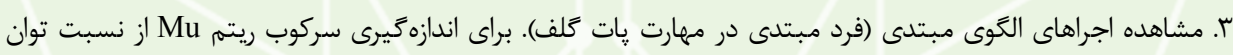
ريتم Mu در حالت مشاهده به توان ريتم Mu در حالت پايه در نواحى مغزى C3، C4 و Cz استفاده شد. يافتهها: آزمون آمارى تحليل واريانس درون گروهى دو راهه نشان داد كه سركوب ريتم Mu بين موقعيتهاى آزمايشى تفاوت معنادارى دارد. نتيجه مقايسه هاى زوجى نيز حاكى از آن بود كه در موقعيت خودالكَودهى، سركوب ريتم Mu به طور معنادارى بيشتر از دو موقعيت ديكر بود. نتيجه كَيرى: بخشى از يافتهها بيانكر آن است كه به علت عدم تطابق بين توانايى اجراى حركت با اجراى الكَىى مشاهده شده، فعاليت نورون هاى آينهاى در موقعيتهاى الكَوى ماهر و الكَوى مبتدى پايينتر بوده است. علت فعاليت بيشتر نورونهاى آينهاى در موقعيت خودالكودهى نيز در جهارجوب نظريه شناختى_اجتماعى Bandura و شباهت الكو_مشاهدهر بحث و تبيين شد.

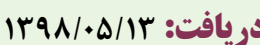

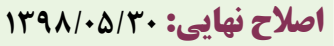

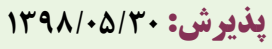
وازههاى كليدى الخودهى Mu سركوب ريتمى سونم نورون هاى آينهاى

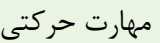

نويسنله مسئول رامين اشرف، دانشكاه شهيد بهشتى، دانشكده علوم ورزشى و تندرستى، گروه علوم رفتارى و شناختى در ورزش، تهران، ايران

ايميل:R_ashraf@sbu.ac.ir

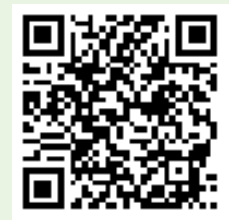

dol doi.org/10.30699/icss.21.2.132

مقدمه

برنامههاى تمرينى در يادكيرى تكاليف مختلف كردند. در اين راستا، مرور يافتههاى حاصل از مطالعات علوم روانشناختى و حركتى معاصر، جندين متغير مستقل سودمند و كارآمد را در يادكيرى مهارتهاى حركتى نشان مى دهد كه يكى از اين متغيرها يادگيرى مشاهدهاى است (ז). يادگيرى مشاهدهاى يا يادگيرى از الكو، استفاده از نمايش به عنوان وسيلهاى
اين واقعيت كه انسان قادر به كسب دانش و مهارتهاى جديدى است، باعث علاقهمندى زياد به روشهاى يادگيرى و متغيرهاى مهمم شده است. يكى از اهداف اصلى در يادگيرى حركتى، شناخت متغيرهاى مستقلى است كه ميزان يادَّيرى را بالا برده، يا مختل كرده و يا نقشى در آن ندارند (1). بدين منظور، يزوهشگران شروع به مقايسه سودمندى 
تقويت فرآيندهاى توجه و يادداري يادگيري مشاهدهاى مىشود. طبق اين نظريه، بالاترين ميزان شباهت الكو_مشاهدهر زمانى رخ مئدهدي

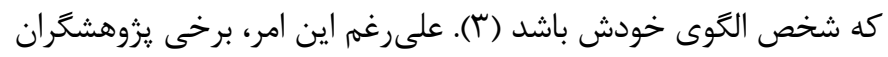

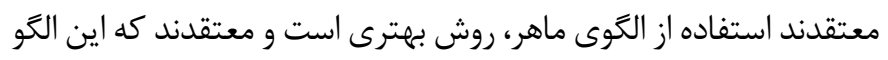

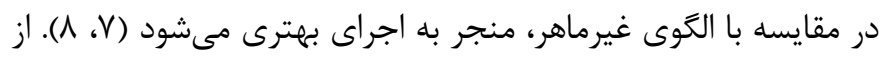

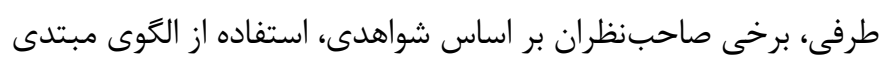

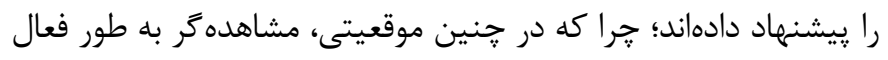
در حل مسئله دركير خواهد شد و اين امر براى يادگيرى سودمند است

با وجود جنين ديدكاههايى در مورد اين كه جه كسى مطلوبترين الكو براى مشاهده است به بحث زيربناى مكانيسم يادكيرى مشاهدهاى، يعنى

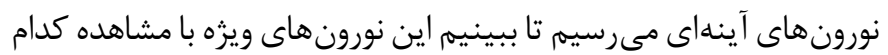

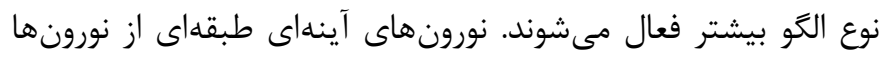

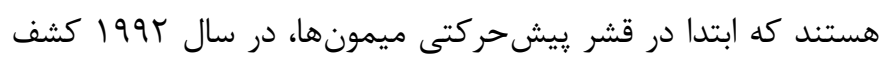

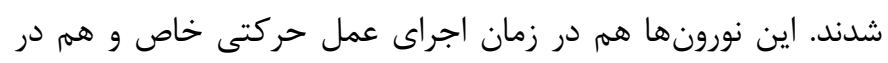
زمان مشاهده اجراى همان عمل توسط فردى ديكر فعال مى شوند (1) (1).

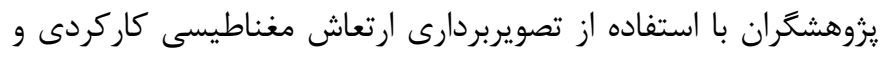
جريان خون نواحى مختلف مغز با تكاليف متعدد به اين نتيجه رسيدند

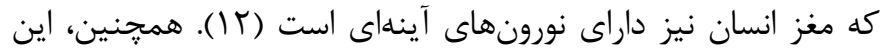

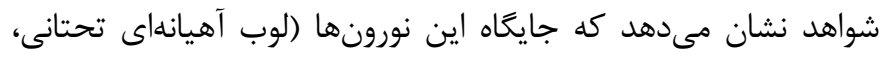

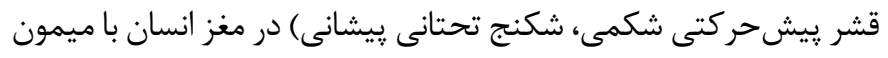

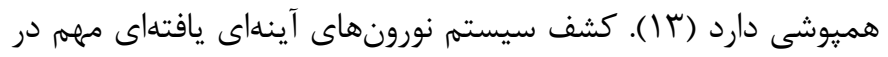

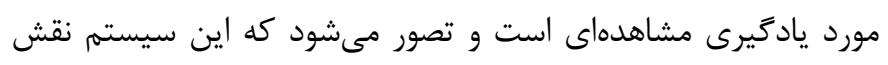

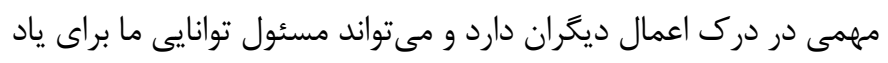

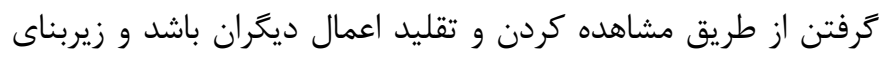

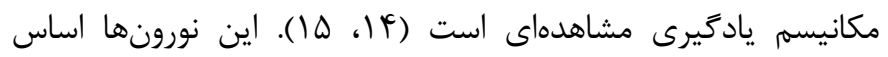

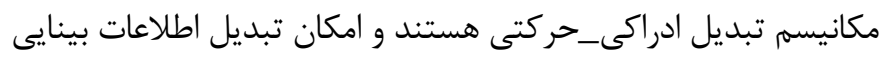

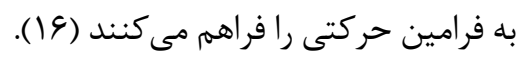
دادهاى مطالعات مرتبط با مهارتهاى حركتى نشان مى دهند كه فعاليت

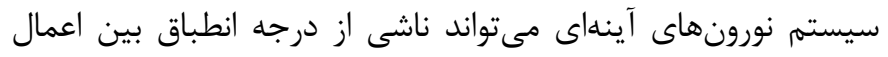

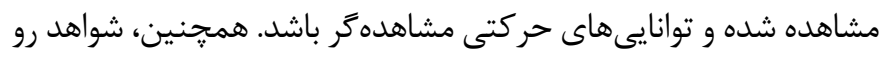

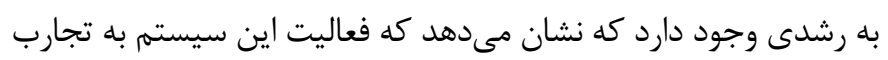

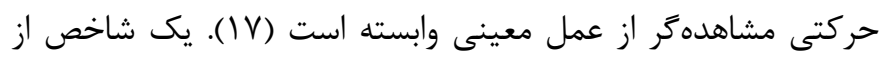

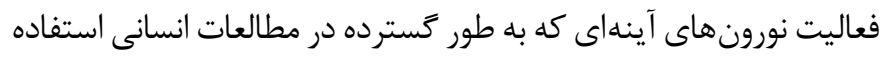

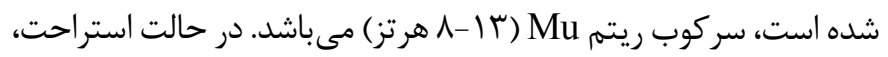
نورونها در منطقه حسى_حركتى به شكل همزمان شليك مى كنند كه منجر به نوسانات با دامنه بزرى امواج الكتريكى مغز در ريته فر كانسى لهى
براى انتقال اطلاعات در مورد جگَونكى اجراى يك مهارت مىباشد (1). الكَودهى، مولفه حياتى در نظريه شناختى_اجتماعى Bandura است

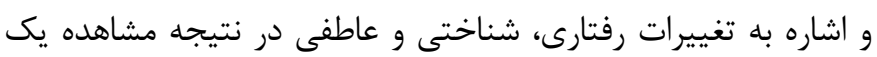

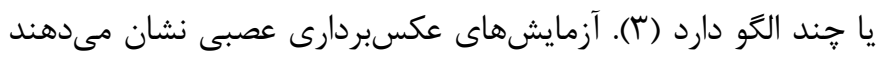

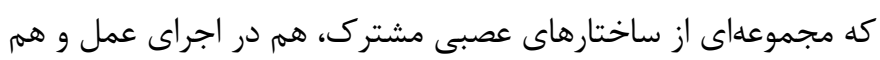

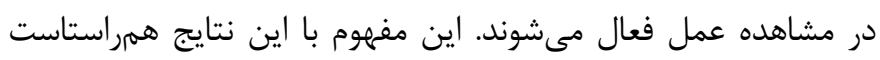

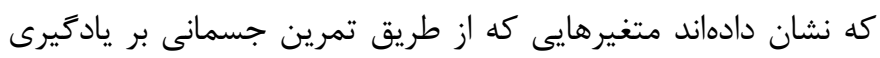

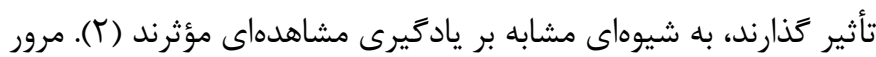
مطالعات مرتبط با يادكيرى مشاهدهاى نشان مىدهد كه عوامل زيادى در مؤثر بودن مداخلات مشاهدهاى نقش دارند. يِيشينه مطالعاتى اين زمينه

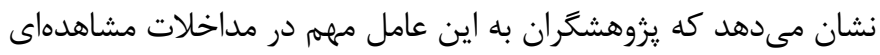

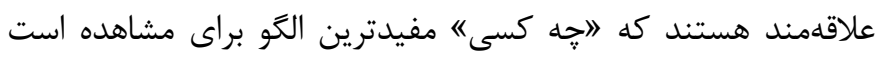

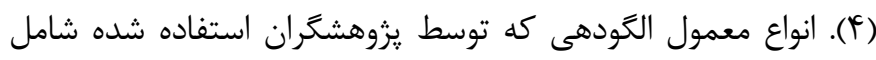

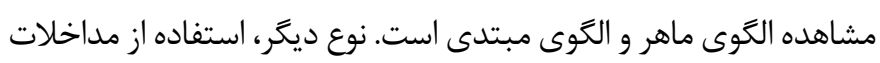

خودالكودهى است (ه).

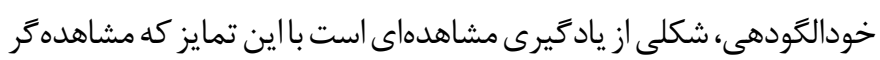

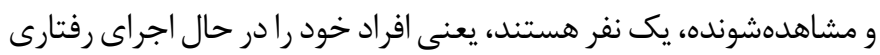
مشاهده كرده و سيس رفتار مورد نظر را تكرار مى كنند (9). عواملى در

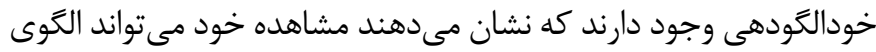

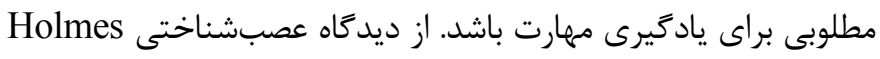

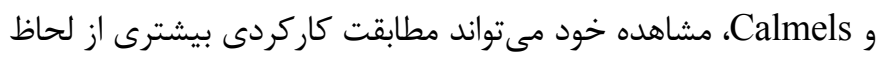

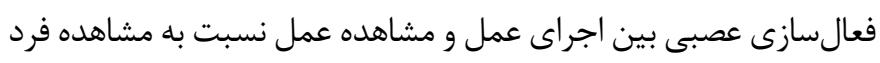

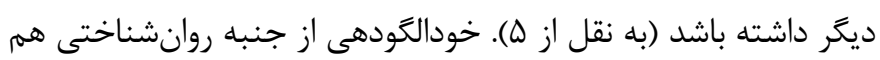

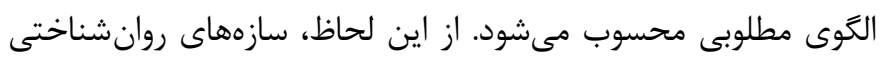

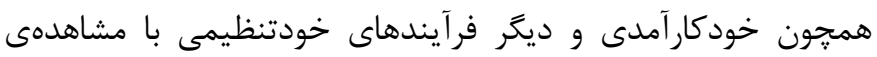

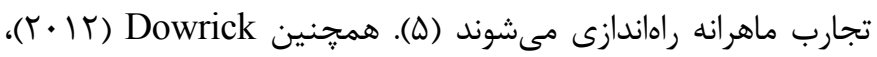
Ste-Marie

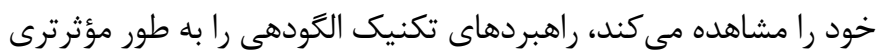

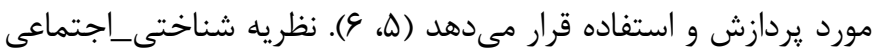

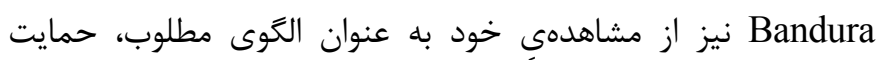

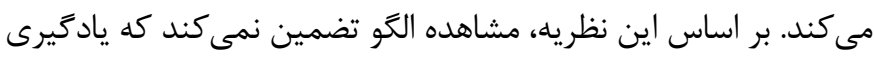

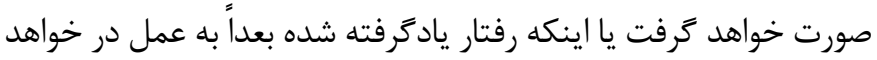

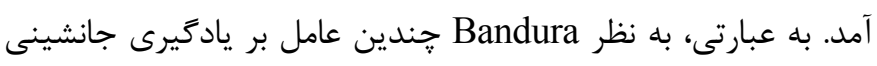

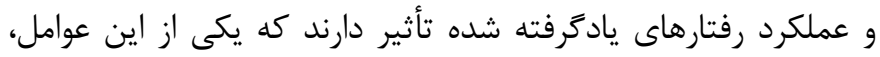

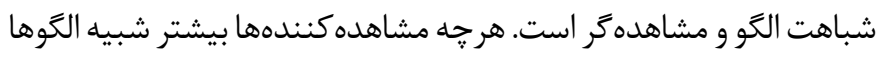

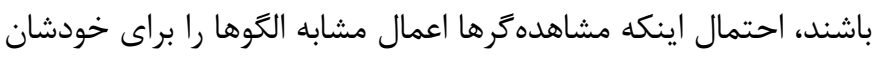

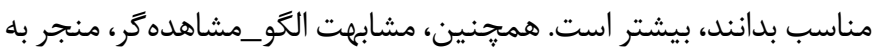




\section{روش كار}

مطالعه حاضر شامل يك طرح درون گروهى با سه مرحله آزمايشي

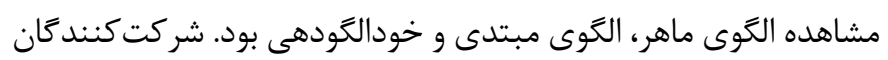

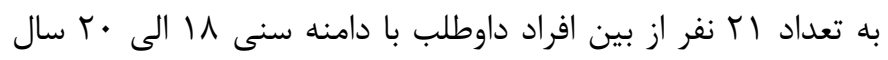

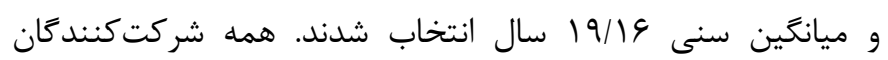

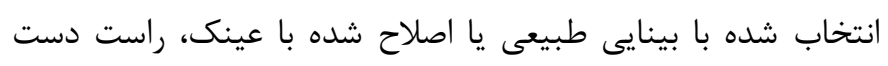

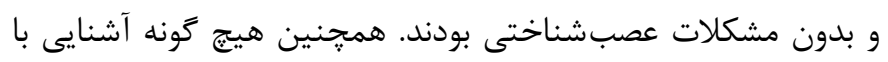

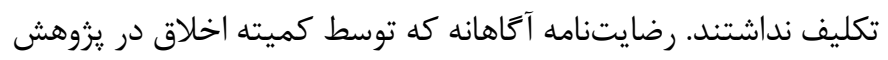

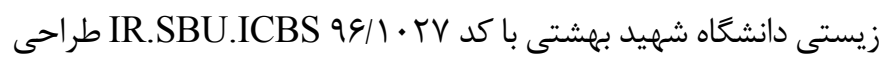

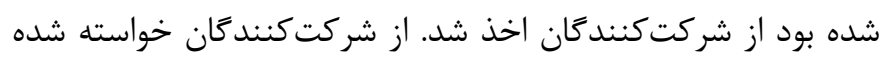

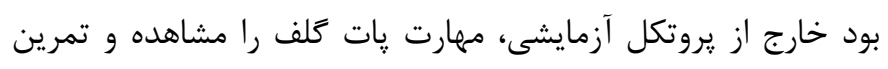

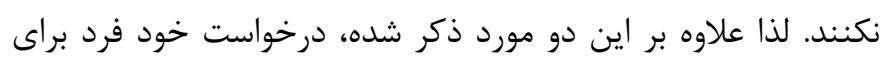

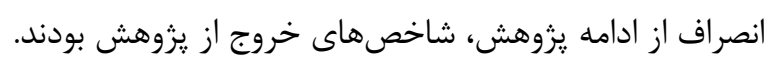

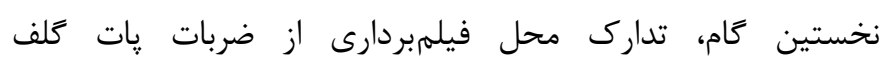

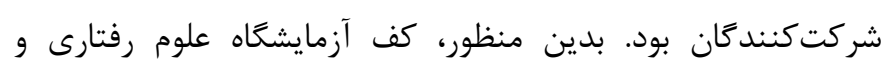

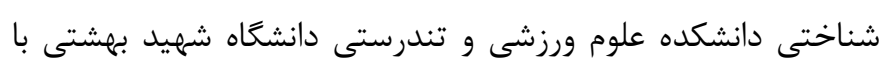

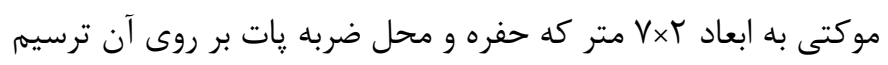

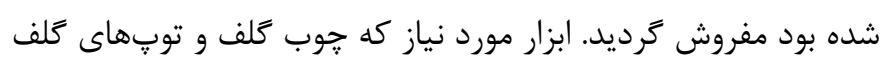

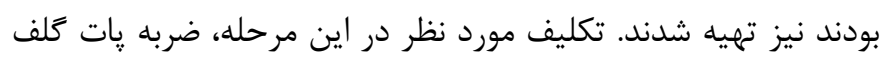

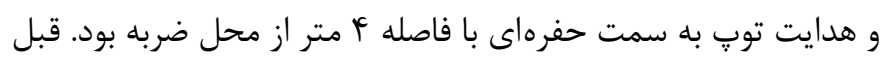
از شروع ضربات پات كلف، ملاحظات ييش از تمرين، ارائه دستور العمل

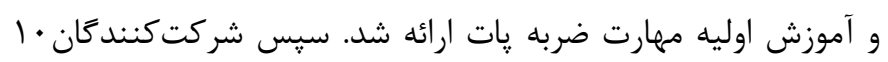

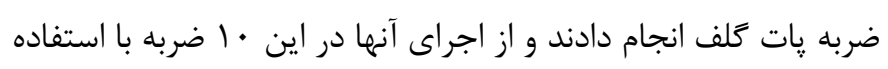
از دوربين فيلمبردارى سونى (Sony Cyber-shot DSC-W830)

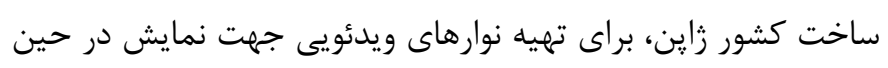

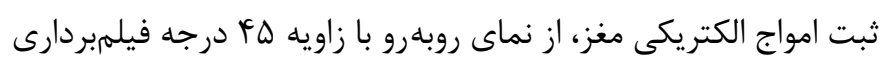

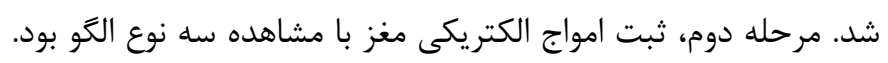

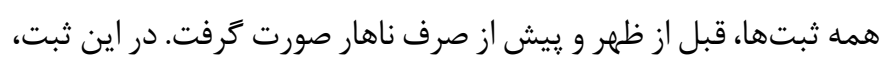

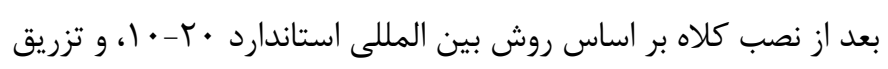

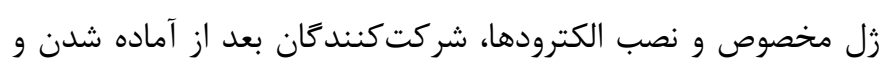

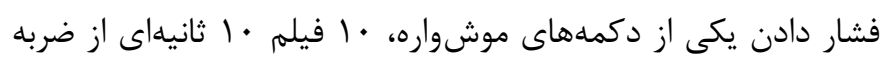

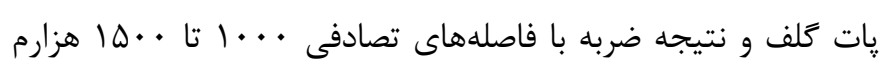

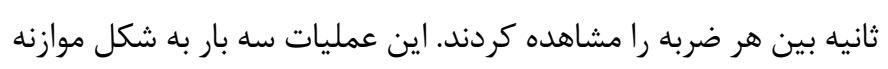

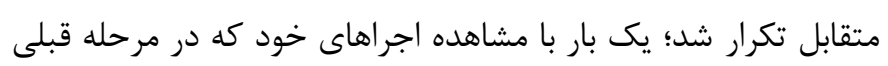

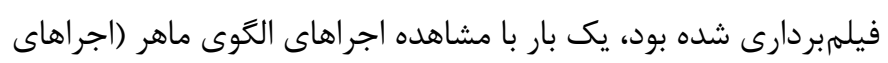

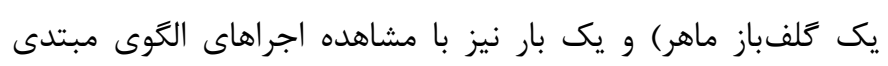

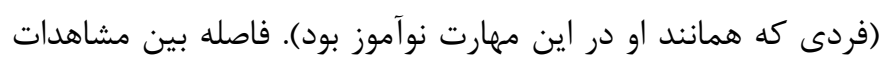

مىشود. زمانى كه افراد حر كتى را مشاهده مى كنند اين نورونها به شكل

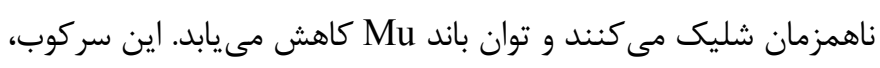

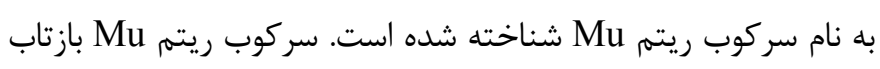
تعديل نواحى حسى_حركتى توسط نورونهاى آينهاى است كه ترجمه

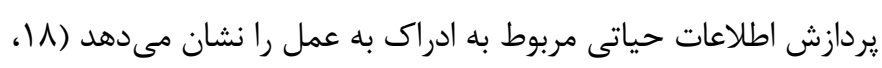

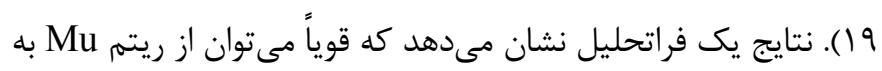
عنوان فعاليت سيستم آينهاى انسان استنباط كرد (• (Y). Calvo-Merino

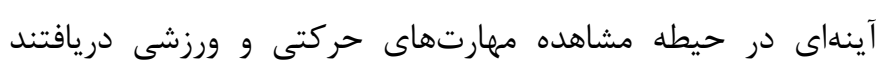

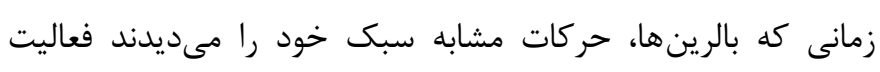

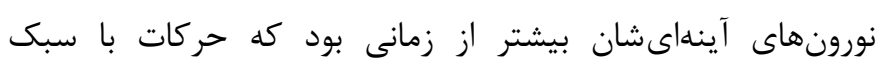

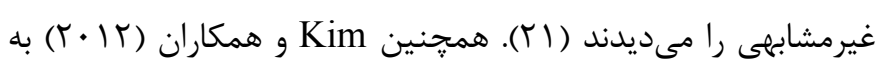

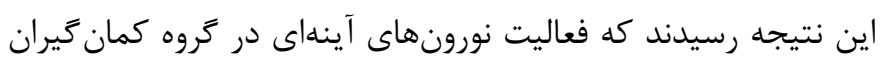

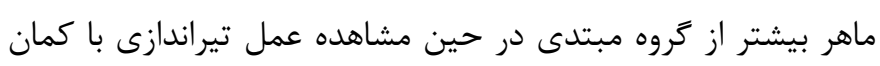

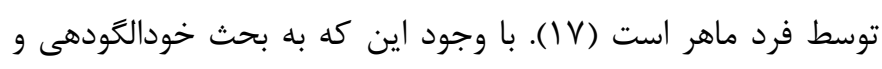

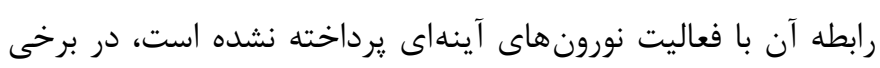

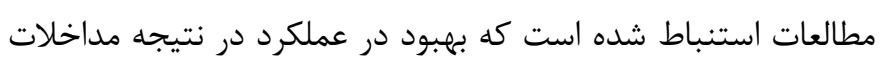

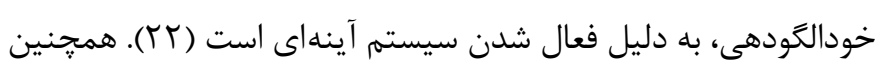

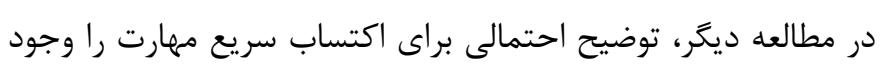

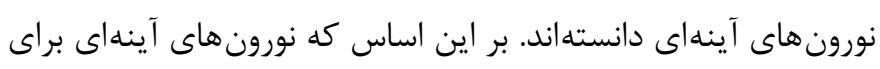

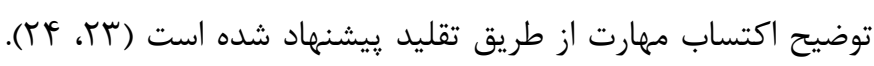

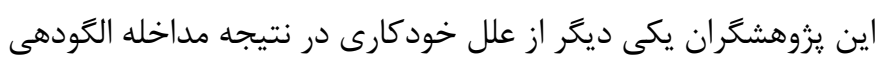

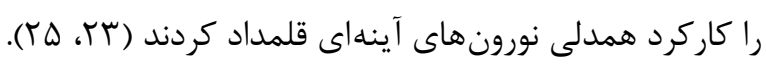

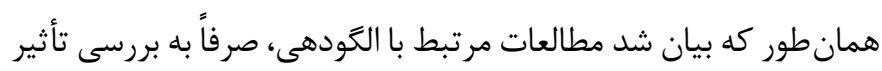

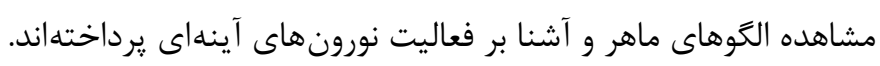

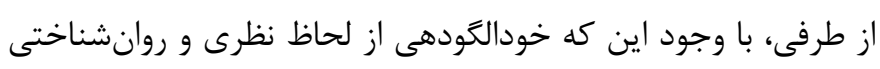

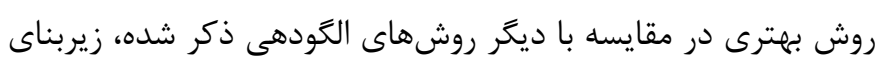

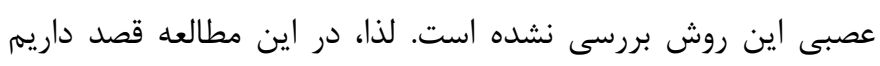

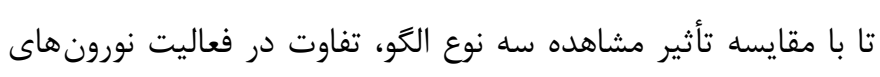

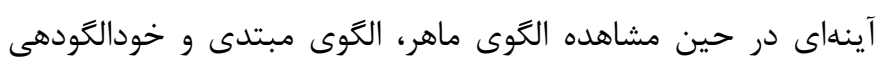

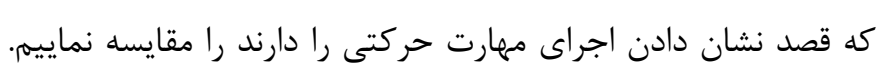

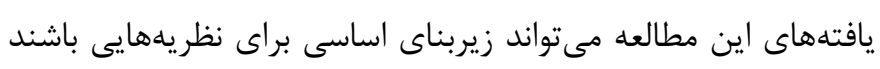

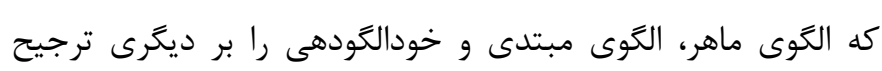

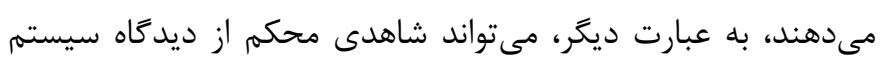

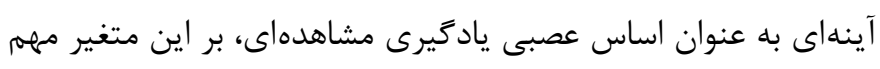

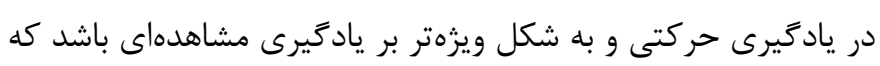
"جه كسى" مفيدترين الخو براى مشاهده است. 
(منطقه مغزى: C3 و C4 C2 تحت نرمافزار SPSS-25 بررسى شدند. سطح معنادارى ه • P P در نظر كرفته شد.

\section{بافته ها}

با توجه به برقرار بودن ييش فرضهايى همجون طبيعى بودن توزيع

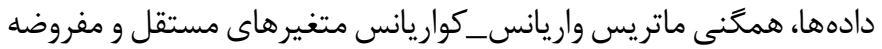
كرويت از آزمون هاى يارامتريك استفاده شد. بدين ترتيب تحليل واريانس دو راهه درون گروهى براى سنجش تأثير سه نوع مداخله (مشاهده الكوى از خود، مشاهده الكوى ماهر و مشاهده الكوى مبتدى) در سه منطقه حسى_حركتى مغز (C3، C4 C4) بر سركوب ريتم Mu استفاده شد.

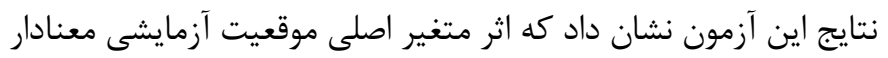

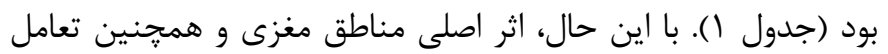

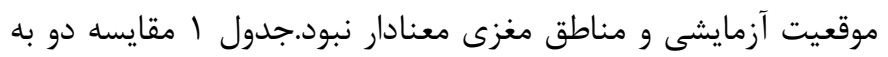

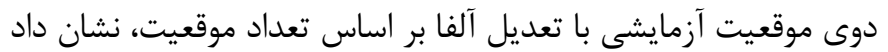
كه موقعيت خودالكودهى با داشتن سركوب ريته Mu بيشتر در مناطق

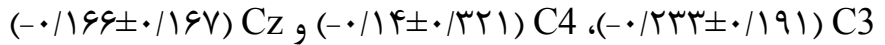
تفاوت معنادارى با ميزان سركوب ريتم Mu موقعيت الكوى ماهر در مناطق

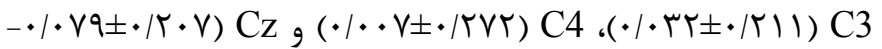

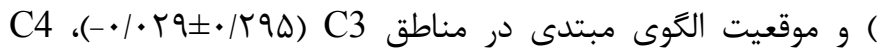
كه موقعيتهاى الكوى ماهر و موقعيت الكَى مبتدى تفاوت معنادارى با هم

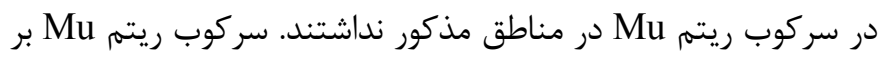
اساس ميانگَين سه منطقه مغزى و همجنين به تفكيك هر منطقه در هر سه موقعيت آزمايشى به ترتيب در نمودار او آ ترسيم شده است. r موقعيت آزمايشى نيز • † ثانيه بود. در هر ب نوع فيلم، مكان، ابزار و زاويه فيلمبردارى شده به طور كامل يكسان بودند. ثبتها با دستخاه ثبت امواج الكتريكى مغز (الكتروانسفالوگرام) به نام بsychlab EEG8 محصول شركت Contact Precision Instruments در يزوهشكده علوم شناختى و مغز دانشگاه شهيد بهشتى تهران صورت كرفت. براى

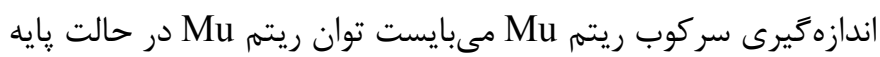

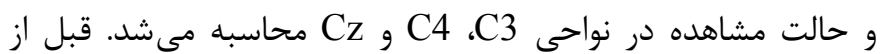
محاسبه اين توانها مرحله ييش يردازش به منظور حذف نويزهاى ناشى از يلك زدن، حركت جشم، حركت سر و... به وسيله جعبه ابزار كه بر روى نرمافزار MATLAB LAB) Fast Fourier) Fرفت. توانها بر اساس تكنيك تغيير سريع فوريه

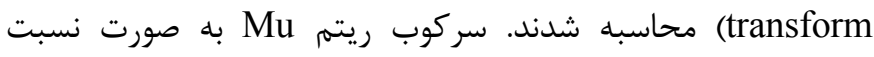

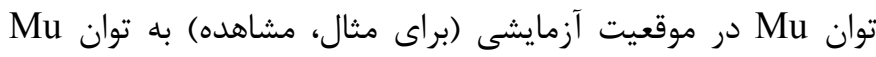

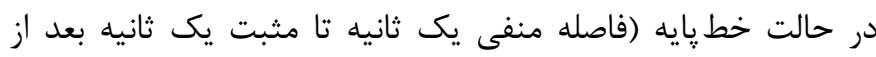

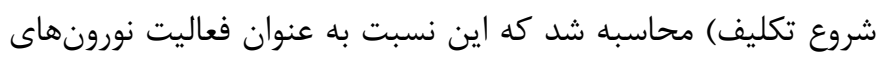

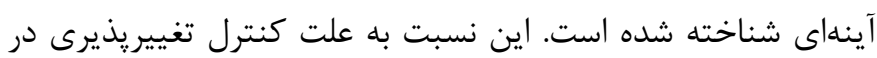
توان مطلق در نتيجه تفاوتهاى فردى همجون ضخامت جمجمه و مقاومت الكترودها صورت مى يرد. همجنين به علت اين كه نسبت دادهها در نتيجه محدوده يايين، به طور ذاتى غيرطبيعى هستند، يك تبديل لكاريتمى نيز براى تحليل استفاده شد. نسبت لكاريتمى كمتر از

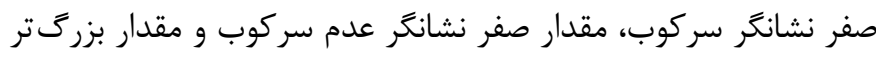
از صفر نشاندهنده افزايش است. دادههاى امواج الكتريكى مغز با با آزمون

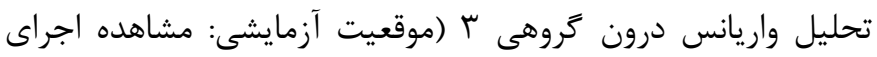

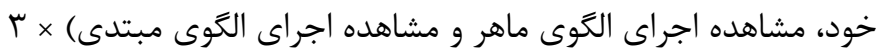

جدول 1. خلاصه نتايج تحليل واريانس دو راهه درون كروهى

\begin{tabular}{|c|c|c|c|c|c|}
\hline اندازه اثر & $\mathbf{P}$ & آماره آزمون & درجه آزادى & مجذوروات & منبع تغييرات \\
\hline$\cdot / r \cdot 4$ & $* \cdot \cdots 1$ & $\Lambda / V \Delta$ & r & I/TAT & موقعيت \\
\hline$\cdot / \cdot V$ & ( & $1 / 499$ & r &.$/ 1 r \wedge$ & مناطق مغزى \\
\hline$\cdot / \cdot c V$ & $\cdot / 419$ & .1911 & f & .119 & تعامل موقعيت و مناطق مغزى \\
\hline
\end{tabular}




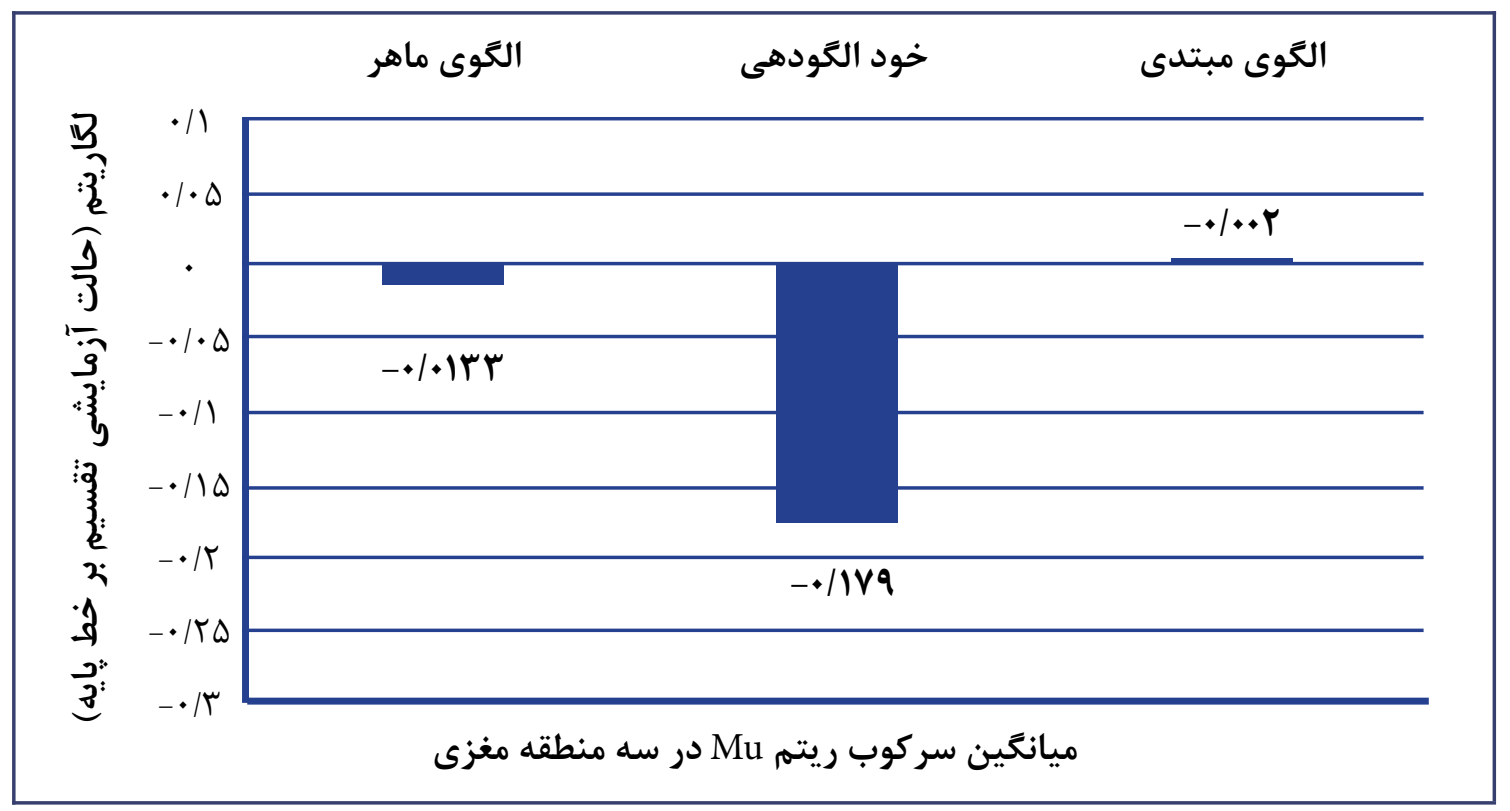

نمودار ا. ميزان سركوب ريتم Mu در موقعيتهاى آزمايشى بر اساس ميانكين سه منطقه مغزى

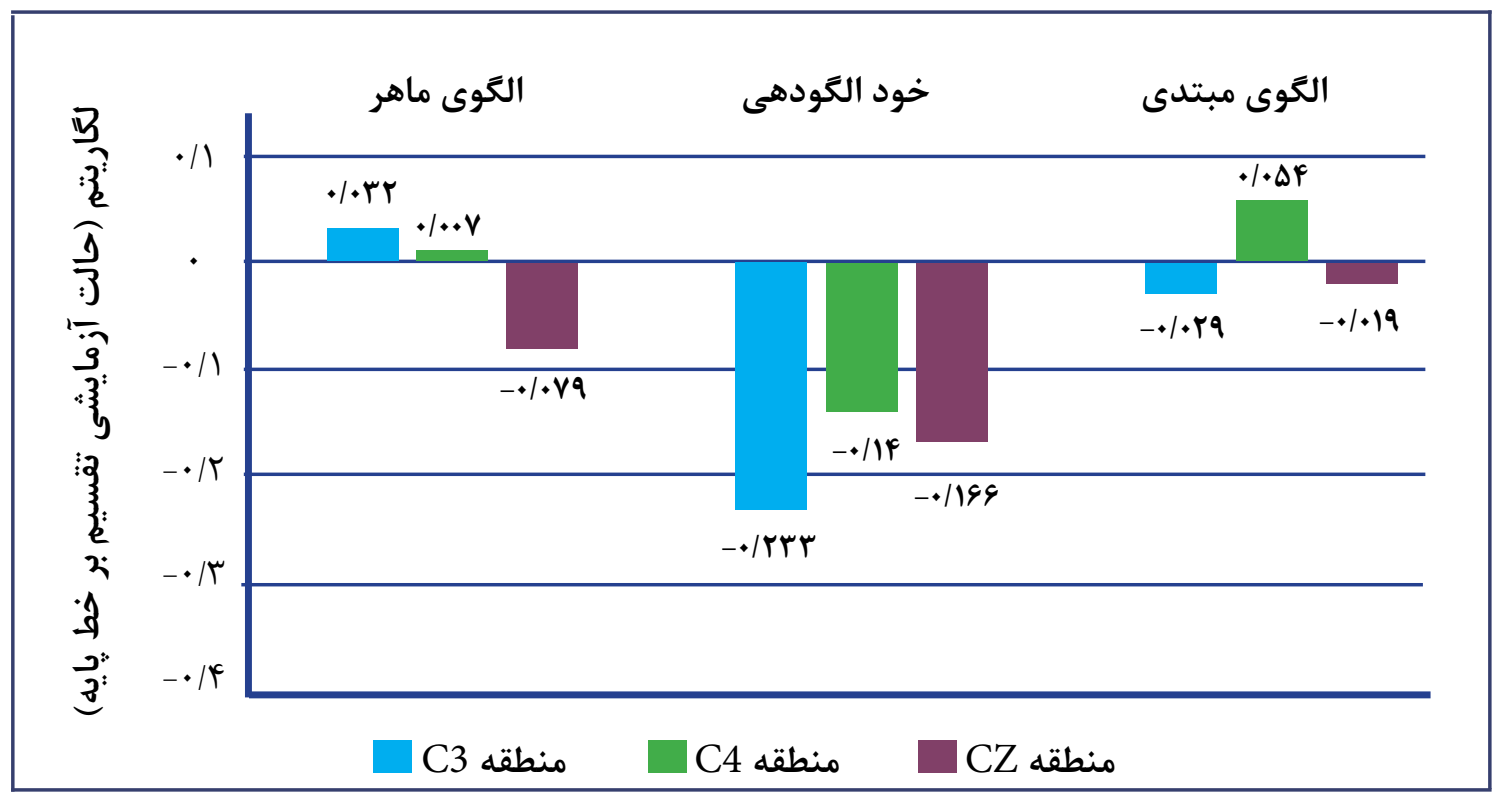

نمودار r. ميزان سركوب ريتم Mu در موقعيتهاى آزمايشى به تفكيك هر سه منطقه مغزى

آينهاى در موقعيت مشاهده الگوى ماهر بيشتر از موقعيت مشاهده الكوى غيرماهر بود (Y)). اين يافته در تناقض با يافتههاى مطالعه حاضر است. يكى از علل ناهمخوانى را مى توان به بحثى در مورد نحوه محاسبه سركوب ريتم Mu دانست. در اين راستا، Hobson و Bishop

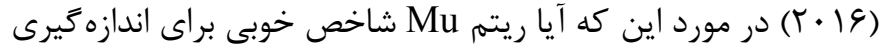
سيستم نورون آينهاى انسان است بحثى را مطرح كردند. بر اساس نظر اين :زوهشخران، ويزگگى كليدى طراحى مطالعات سركوب ريتم Mu، مقايسه موقعيت آزمايشى با موقعيت خط يايه است كه انتظار مىرود
هدف مطالعه حاضر، بررسى تأثير خودالگودهى، الگوى ماهر و الگوى مبتدى بر فعاليت نورون هاى آينهاى در افراد مبتدى بود. نتايج فعاليت نورونهاى آينهاى در هر سه موقعيت حاكى از فعاليت بيشتر اين نورونها در موقعيت خودالكودهى بود. اين سركوب بيشتر ريتم در موقعيت آزمايشى كه نسبت به خط پايه استنباط شده است، در هر سه منطقه حسى_حركتى C3، C4 Cz Cz مشاهده شد. همجنين تفاوتى بين موقعيتهاى الگوى ماهر و الگوى مبتدى مشاهده نشد. مطالعه حاتمى و همكاران (9 (1) نشان داد كه فعاليت نورونهاى 
الكو را در ذخيره حركتى خود نداشتند و همجنين، مقدار انطباق بين اجراى مشاهده شده پات گلف و توانايى خود در اجراى همان حركت را بسيار پايين دريافتهاند. به عبارتى ديخر، جون در تكليف پات كلف مهارتى نداشتند و هنوز اين تكليف را ياد نكرفته بودند فعاليت نورون هاى آينهاى نيز كمتر بوده است.

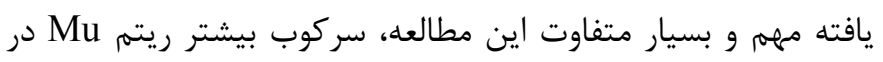

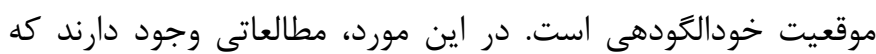
مى توان آنها را به نحوى به اين يافته يزوهش حاضر ارتباط داد. براى مثال، Gastaut ( اله (1)، زمانى كه هنوز نورونهاى آينهاى كشف نشده بودند، ززارش كرد ريتم Mu در زمانى كه فرد خود را بر روى صفحه نمايش مى بيند، بلوكه مى شود (9)). مطالعاتى نيز وجود دارند كه استنباط كردهاند با مشاهده خود، نورونهاى آينهاى تحت تأثير قرار گرفتهاند، با وجود اين كه ثبت امواج الكتريكى مغز نداشتهاند. Coulson نقص لبخند بعد از فلج اعصاب صورت را داشتند، آنان بعد از تمرين

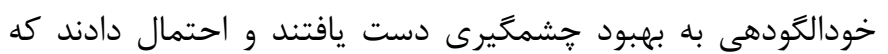
ديدن لبخند خود در نوار ويدئويى، نورونهاى آينهاى را براى تسهيل

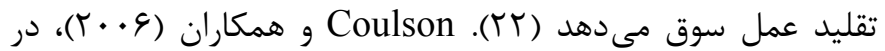
مطالعهاى ديخر به نتايج مشابهى با روش خودالكودهى دست يافتند و توضيح احتمالى براى اكتساب سريع اين مهارت را وجود نورونهاى آينهاى دانستهاند. بر اين اساس كه نورونهاى آينهاى براى توضيح اكتساب مهارت از طريق تقليد بيشنهاد شده است، براى مثال تقليد ذاتى صورت، در حركات صورت بين مادران و نوزادان با سن بr بران

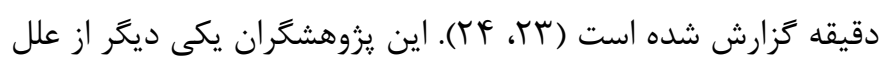
خودكارى در نتيجه مداخله الكودهى را كاركرد همدلانه نورونهاى

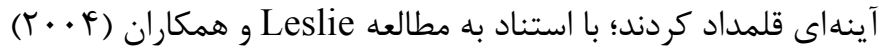
كه ياسخهاى عاطفى همدلى در سيستم ليمبيك را به نورونهاى آينهاى مربوط دانستهاند (سT، ه广). اين نتايج همسو با يافته مطالعه حاضر است كه با مشاهده خود در موقعيت خودالكودهى، فعاليت نورونهاى آينهاى بيشتر شده است.

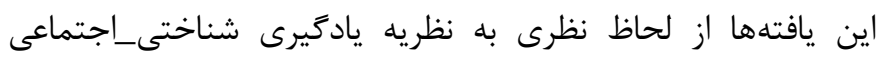
نيز مربوط است. (19VV) Bandura ) معتقد است توجه، آغازگر فر آيند الكودهى است، توجه به عنوان يك مكانيسم انتخابى تعيين

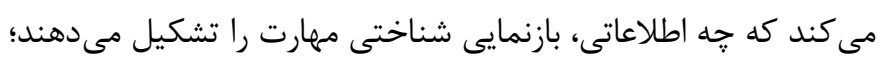
بنابراين اين سؤال مطرح مى شود كه كدام عامل تعيين مى كند كه جه جيزى مورد توجه قرار بخيرد؟ (•r). به عقيده Bandura، مهرمترين عامل مؤثر بر يادگيرى جانشينى و عملكرد رفتارهاى يادگرفته شده شباهت
سيستم نورونهاى آينهاى در موقعيت خط پايه فعال نشود. به همين علت، نحوه انتخاب خط يايه براى محاسبه ريتم Mu، حياتى و مهرم است، لذا در اين مطالعه به اهميت روششناسى خط پايه يرداخته شده است و بيان شد كه استفاده از خط يايه استراحت روش مناسبى براى محاسبه ريتم Mu نيست، بلكه بايد از خط يايه درونتكليفى

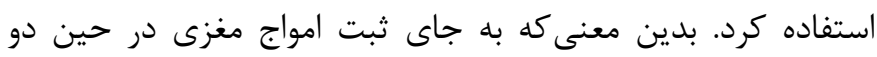

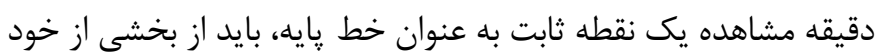
تكليف كه محرك هنوز ظاهر نشده است استفاده كرد (YV). لذا به نظر مىرسد يكى از علل تفاوت در ناهمخوانى يافتههاى مطالعه حاضر با مطالعه حاتمى و همكاران، استفاده از خط پايه متفاوت براى استنباط فعاليت نورونهاى آينهاى است، جرا كه در مطالعه حاضر از خط يايه درون تكليفى و در مطالعه آنان از خط پايه استراحت استفاده شده بود. عدم تفاوت بين فعاليت نورون هاى آينهاى در دو موقعيت الكوى ماهر و الكوى مبتدى با يافتههاى مطالعات Calvo-Merino و همكاران

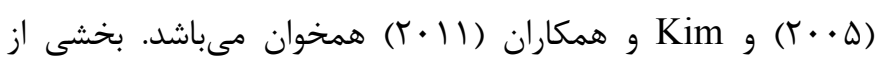

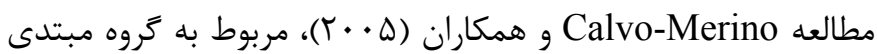
بود كه هر دو نوع حركات باله و كايوريا را مشاهده كردند. نتايج اين بخش حاكى از عدم تأثير نوع محرك (مشاهده عكسهاى حركات ماهرانه باله و مشاهده عكسهاى حركات ماهرانه كايوريا) بر فعاليت نورون هاى آينهاى شركت كنندگًان مبتدى بود ( آY). همجنين Kim و همكاران (11 · r) به اين نتيجه دست يافتند كه فعاليت نورونهاى آينهاى شركت كنندگان مبتدى در مهارت تيراندازى با كمان، در زمان

مشاهده اجراى كمانداران ماهر، كمتر از افراد ماهر مى باشد (IV). علت فعاليت كمتر نورونهاى آينهاى در دو موقعيت مشاهده الكوى ماهر و الكوى مبتدى كه همخوان با مطالعات ذكر شده است را مى توان به موضوع ذخيره حركتى مربوط دانست. در اين راستا، شواهدى وجود دارد كه نشان مى دهد كه تنها اعمالى كه در ذخيره حركتى ما هستند بر فعاليت سيستم نورونهاى آينهاى مؤثرند (Y^). به عبارت ديخر، زمانى كه عمل اجرا شده توسط الكو، جزء ذخيره حركتى مشاهدهر نيست، فعاليت نورونهاى آينهاى يايين است. همجنين پِيشنهاد شده است كه فعال شدن سيستم نورونهاى آينهاى مىتواند مربوط به درجهاى از انطباق بين اعمال مشاهده شده و قابليت حركتى مشاهدهر باشد بـد (IV) (IV) بدين معنى كه، زمانى مشاهده يك الخو بر فعاليت نورونهاى آينهاى مؤثر است كه مشاهدهر بين اجراى الخوى مشاهده شده و قابليت حركتى خود مشابهتى بيابد. لذا به نظر مىرسد شركت كنند مطالعه حاضر در موقعيتهاى الگوى ماهر و الگُى مبتدى، بدين علت فعاليت نورون هاى آينهاى كمترى داشتند كه حركت اجرا شده توسط 
نداشته باشد. نورونهاى آينهاى به عنوان مكانيسم زيربنايى يادگيرى مشاهدهاى ذكر شدهاند، لذا فعالسازى بيشتر آنها مىتواند ملاحظات تمرينى مهمى در يادَيرى مهارتهاى حركتى داشته باشد. لذا توصيه مى گردد مربيان با استفاده از مداخلات خودالكودهى در يادگيرى مهارتهاى حركتى و ورزشى، باعث واكنش بيشتر نورونهاى آينهاى و

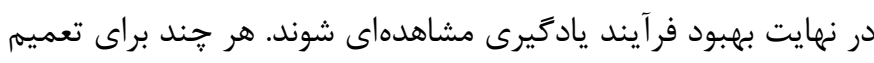
اين نتايج و اين نتيجه كيرى به يادكيرى مهارتهاى حركتى و ورزشى نياز به مطالعاتى است كه شامل فرآيند يادگيرى همراه با اندازهيرى فعاليت نورون هاى آينهاى در مراحل مختلف باشد. همجنين ييشنهاد مىشود از ديخر مداخلات خودالكودهى مثل خود مرورگرى مثبت و خودالكودهى

$$
\text { ييش خوراند نيز استفاده شود. }
$$

\section{تشكر و قارقاذى}

مقاله حاضر از ياياننامه دكترى مصوب در دانشكده علوم ورزشى و تندرستى دانشگاه شهيد بهشتى تهران با عنوان لاتأثير خودالكودهى، مهيك الخوى ماهر و الخوى در حال يادگيرى بر فعاليت نورونهاى آينههاى و يادكيرى يك تكليف حركتى" استخراج شده است و ثبت امواج مغزى در يزوهشكده علوم شناختى و مغز اين دانشخاه صورت گرفته است. لذا نويسندكان مراتب تشكر خود را از مسئولين و كاركنان اين يروهشكده و همجنين از همه شركت كنندكان در اين يزوهش اعلام مىنمايند.

\section{References}

1. Schmidt RA, Lee TD, Winstein C, Wulf G, Zelaznik HN. Motor control and learning: A behavioral emphasis. 6th ed. Champaign: Human Kinetics;2018.

2. Wulf G, Shea C, Lewthwaite R. Motor skill learning and performance: A review of influential factors. Medical education. 2010;44(1):75-84.

3. Schunk DH. Learning theories: An educational perspective. 6th ed. London: Pearson;2012.

4. Ste-Marie DM, Law B, Rymal AM, Jenny O, Hall C, McCullagh P. Observation interventions for motor skill learning and performance: An applied model for the use of observation. International Review of Sport and Exercise Psychology. 2012;5(2):145-176.

5. Ste-Marie DM, Vertes K, Rymal AM, Martini R. Feed for-
الكو و مشاهدهر است. هر خه مشاهده كنندها بيشتر شبيه الكوها باشند، احتمال اين كه مشاهدهر ها اعمال مشابه الكوها را براى خودشان مناسب بدانند، بيشتر است. همجنين مشابهت الخو_مشاهدهرَ، منجر به تقويت فرآيندهاى توجه و ياددارى يادكيرى مشاهدهاى مىشود كه در نتيجه، فوايد يادكيرى از طريق فرآيند مشاهده افزايش مىيابد. طبق اين نظريه، بالاترين ميزان شباهت الكو_مشاهدهر زمانى رخ مي دهد كه شخص الكوى ئرى خودش باشد (ب). به عبارتى زمانى كه مشابهت بين الكو_مشاهده باشد، مشاهدهر بيشتر به مهارت و تكليف مشاهده شده توجه مى كند. لذا به نظر مىرسد كه اين همان اتفاقى است كه در يافته يزوهش حاضر در موقعيت خودالكودهى رخ داده است. به عبارتى، شرك كنندگان در موقعيت خودالكودهى، با مشاهده خود در حال اجراى مهارت يات گلف، به علت مشابهت بالا، بيشتر از دو موقعيت ديخر به الكو (خود) توجه كردهاند، اتفاقى كه در مطالعه Gastaut ( اله9 1) نيز رخ داده است.

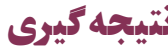

به طور كلى، مىتوان نتيجه گرفت كه خودالكودهى به دليل بالاترين شباهت بين الكو_مشاهدهر،، منجر به توجه بيشتر در حين مشاهده مهارت و در نتيجه فعاليت بيشتر نورونهاى آينهاى مىشود، حتى زمانى كه مشاهدهر حركت مشاهده شده را در ذخيره حركتى خود

ward self-modeling enhances skill acquisition in children learning trampoline skills. Frontiers in Psychology. 2011; 2:155.

6. Dowrick PW. Self-model theory: Learning from the future.

Wiley Interdisciplinary Reviews: Cognitive Science. 2012;3(2):215-230.

7. McCullagh P, Meyer KN. Learning versus correct models: Influence of model type on the learning of a free-weight squat lift. Research Quarterly for Exercise and Sport. 1997;68(1):5661.

8. Landers DM, Landers DM. Teacher versus peer models: Effects of model's presence and performance level on motor behavior. Journal of Motor Behavior. 1973;5(3):129-139.

9. Martens R, Burwitz L, Zuckerman J. Modeling effects on motor performance. Research Quarterly. American Alliance for 
Health, Physical Education and Recreation. 1976;47(2):277291.

10. Hebert EP, Landin D. Effects of a learning model and augmented feedback on tennis skill acquisition. Research Quarterly for Exercise and Sport. 1994;65(3):250-257.

11. Gazzaniga MS. The cognitive neurosciences. 4th ed. Cambridge: MIT Press;2009.

12. Rosenbaum DA. Human motor control. 2nd ed. Cambridge: Academic Press;2009.

13. Aziz-Zadeh L, Koski L, Zaidel E, Mazziotta J, Iacoboni M. Lateralization of the human mirror neuron system. Journal of Neuroscience. 2006;26(11):2964-2970.

14. Cattaneo L, Rizzolatti G. The mirror neuron system. Archives of Neurology. 2009;66(5):557-560.

15. Van Gog T, Paas F, Marcus N, Ayres P, Sweller J. The mirror neuron system and observational learning: Implications for the effectiveness of dynamic visualizations. Educational Psychology Review. 2009;21(1):21-30.

16. Lago-Rodríguez A, Cheeran B, Koch G, Hortobagy T, Fernandez-del-Olmo $\mathrm{M}$. The role of mirror neurons in observational motor learning: An integrative review. European Journal of Human Movement. 2014; 32:82-103.

17. Kim YT, Seo JH, Song HJ, Yoo DS, Lee HJ, Lee J, et al. Neural correlates related to action observation in expert archers. Behavioural Brain Research. 2011;223(2):342-347.

18. Alhajri N, Hodges NJ, Zwicker JG, Virji-Babul N. Mu suppression is sensitive to observational practice but results in different patterns of activation in comparison with physical practice. Neural Plasticity. 2018; 2018:8309483.

19. Oberman LM, Hubbard EM, McCleery JP, Altschuler EL, Ramachandran VS, Pineda JA. EEG evidence for mirror neuron dysfunction in autism spectrum disorders. Cognitive Brain Research. 2005;24(2):190-198.

20. Fox NA, Bakermans-Kranenburg MJ, Yoo KH, Bowman LC, Cannon EN, Vanderwert RE, et al. Assessing human mirror activity with EEG mu rhythm: A meta-analysis. Psychological Bulletin. 2016;142(3):291-313.

21. Calvo-Merino B, Glaser DE, Grèzes J, Passingham RE, Haggard P. Action observation and acquired motor skills: An FMRI study with expert dancers. Cerebral Cortex. 2004;15(8):12431249.

22. Coulson SE, Adams RD, O’Dwyer NJ, Croxson GR. Physiotherapy rehabilitation of the smile after long-term facial nerve palsy using video self-modeling and implementation intentions. Otolaryngology—Head and Neck Surgery. 2006;134(1):48-55. 23. Coulson SE, Adams RD, O’Dwyer NJ, Croxson GR. Use of video self-modelling and implementation intentions following facial nerve paralysis. International Journal of Therapy and Rehabilitation. 2006;13(1):30-35.

24. Meltzoff AN. Elements of a developmental theory of imitation. In: Meltzoff AN, Wolfgang P, editors. The imitative mind: Development, evolution, and brain bases. Cambridge: Cambridge University Press;2002. pp. 19-41.

25. Leslie KR, Johnson-Frey SH, Grafton ST. Functional imaging of face and hand imitation: Towards a motor theory of empathy. Neuroimage. 2004;21(2):601-607.

26. Hatami. F, Tahmasbi. F, sheikhi. S. The effects of model skill level on $\mathrm{Mu}$

rhythm suppression in basketball lay-up shot. Motor Behavior. 2017;9(28):141-154. (Persian)

27. Hobson HM, Bishop DV. Mu suppression-a good measure of the human mirror neuron system? Cortex. 2016; 82:290-310. 28. Stevens JA, Fonlupt P, Shiffrar M, Decety J. New aspects of motion perception: selective neural encoding of apparent human movements. Neuroreport. 2000;11(1):109-115.

29. Gastaut H. Electrocorticographic study of the reactivity of rolandic rhythm. Neurological Review (Paris). 1952;87(2):176182.

30. Bandura A. Social foundations of thought and action: A social cognitive theory. 1st ed. New Jersy: Prentice Hall;1986. 